\title{
Translating psalms for Africa today: Involving the community and transmitting through performance
}

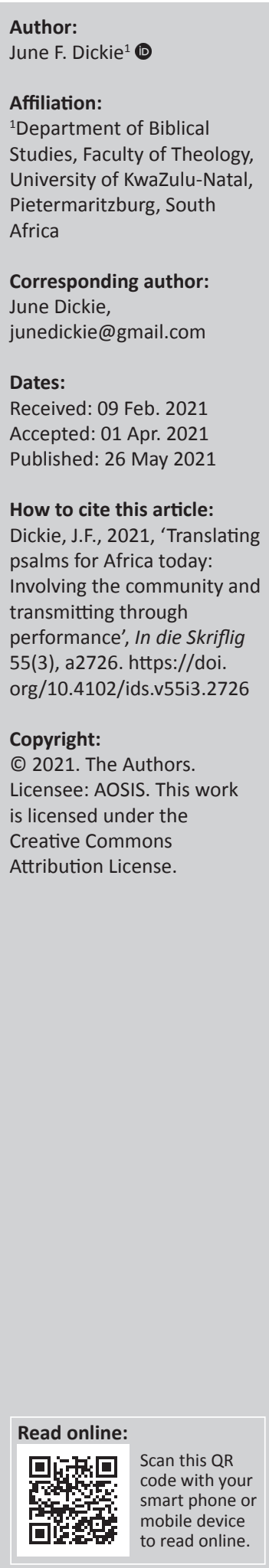

Psalms, being poems, need to be translated as poems using the poetic features of the receptor language. Official translators are not always poetically sensitive, but many community members are highly skilled word-artists, keen to participate in the translation process. Further, poems are always performed before an audience, and thus translated psalms need to include performance features as part of the translation. These two aspects of translating psalms offer advantageous possibilities for those translating biblical poetry. The notion of community involvement challenges the idea of 'authority resting with the trained translators or consultant', but the Skopos Theory reminds us that there can be many translations of a psalm, serving different purposes. This article describes the results of an empirical study including Zulu youth (interested in poetry and music) in the translation of some praise psalms. The idea of interpreting and communicating psalms as oral performances was also tested by presenting the translations as performances before an audience. Four Zulu youth groups participated in the study, each spending five days learning the principles of translation, poetic devices (in Hebrew and isiZulu), features of local music and oral communication style. They studied, translated and presented through oral performance three praise psalms before an audience of adults and peers. The isiZulu translations were evaluated primarily using Wendland's criteria for a literary-rhetorical translation (viz. artistry, aurality and acceptability), but attention was also given to the traditional criteria of faithfulness to the Hebrew, naturalness and clarity. Many of the translations showed creativity balanced with accuracy and gave insights into the exegesis of the psalms. They also used traditional rhythm and features of local poetry and music, and engaged the audience using aspects of performance art. The study highlighted the opportunity available to a translator of psalms to engage local oral artists to participate in the process, either in a parallel project which can feed into the official project, or as a valuable means of Scripture Engagement. Being able to experience the translation process and present psalms in a way meaningful to the local culture has many advantages which need to be explored.

Contribution: Engaging the local community in a significant way is key to the success of a translation project. Beyond simply being 'reviewers', this methodology offers opportunity for greater involvement in the translation of poetry. Further, using oral performance to present psalms actively, engages the community, resulting in far higher acceptability, memorability and perceived relevance.

Keywords: Bible translation; Psalms; community involvement; performance; empirical studies; Africa; Zulu.

\section{Introduction}

\section{Need for aural Scriptures}

In 1997, the Bible Society of South Africa, aware of the large number of people in the country unable to access printed Scripture, researched the viability of aural Scriptures in the languages of South Africa. However, the research shows that simply recording written text onto audio media is ineffective in communicating with those who are not literate (Hermanson 2004:51). Rather, as Crafford (1997:11) notes, what is needed is a special translation that is based on the actual structure of oral discourse of the culture in which we are translating'. A pilot project was then launched (in Southern Sotho), but unfortunately the translators struggled to distinguish oral features in the text (such as repetition and cyclicity) from cultural aspects. Despite not being highly successful, this initiative did point the way forward. At the time Hermanson (2004) noted: 
Any future translation, whether intended for oral recording or as a written text which is nevertheless read aloud to congregations, [must pay] close attention to the oral features of the Hebrew text and to the oral features of Zulu. Doing so ... will result in a translation which flows fluently, in language which speaks not only to the Zulu mind, but also to the Zulu heart. (p. 58)

\section{Need for biblical poetry to be translated poetically}

This is particularly important when it comes to translating poetry. The great linguist and Bible translator, Eugene Nida, refers to an incident that occurred during his years as translation secretary for the Bible Societies. He (Nida

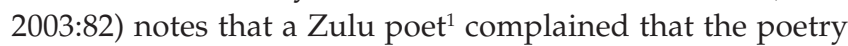
in the 1959 (isiZulu) version of the Book of Psalms was very unsatisfactory. He asked to be permitted to make a revision of the translation, following the pattern of Zulu traditional poetry (izibongo). Nida (2003) claims that his effort was very successful, and concludes:

Some of the Zulu poets are extremely skilled in producing praise poems extemporaneously, for which they draw on a long tradition of poetic forms to praise guests and those who accomplish great exploits. (p. 82)

\section{Need for contemporary media in communicating the Scripture}

Apart from the need for African Scriptures, which are accessible aurally and which utilise the power of indigenous oral art, there is also the need for Scriptures to be presented to the millennial generation, using contemporary media. Foley (2012) asserts that new media (e.g. oral performance) can 'restore at least some of the original dynamism' of the original texts. As Bassnett (2014:153-157) notes: 'Embodied performances can be helpful in stretching our ideas about what translation is.'

\section{Need for communities to own the translations}

The benefits of 'community input' have long been recognised by Bible translators, but from my many years of experience in Bible translation, it is the area given least attention. With isiZulu changing so rapidly (with many Zulu children now attending English-medium schools), the need to have a finger more securely on the pulse of a language seems to be critical. Years and years are spent preparing a Bible translation, and yet a lack of attention to changes in the language can render a new translation unhelpful.

In the past, translation of biblical material has been strongly reserved for 'the professionals'. However, poetry requires a gift that not every translator has. Yet, there are many in the church with poetic talent who would value contributing to this task. Even if the products of such creativity are not 'the authorised version' of a psalm, much is gained by both

1.Nida did not indicate the name of this poet, but it could have been Bethuel Blose Ndelu, a Lutheran schoolteacher and poet, who later became one of the translators on the 1986 BSSA revision (This author was in personal communication with Eric Hermanson in 2015, and that is what he was told). the artists and the audience through the former's participation in such an activity.

\section{Helpful theories in developing a suitable methodology}

Several theories promote useful ideas for Bible translation which meets these needs. Firstly, insights gained from Orality Criticism (e.g. Foley 1995) encourages the translation of psalms which are easily heard. Secondly, Performance Criticism (e.g. Rhoads 2006) promotes the incorporation of performance features as part of the communicated message. This makes the contents of the message far more engaging and memorable. Thirdly, the literary-rhetorical approach of Wendland (2004) is useful in ensuring that the literary beauty and rhetorical power of the Hebrew text is captured, resulting in a translated psalm which sounds like a poem (and more so, an indigenous poem). The underlying theory is that of functional equivalence in which poetic devices are used in the receptor language which serve similar functions as those in the original.

Fourthly, the ideas of Reception Theory (e.g. Darr 1998) and crowd-sourcing (Shirky 2010) help the receptor community own the translation. Reception Theory posits that audience members bring their own context into the interpretation of the ancient text. Crowd-sourcing plays to the millennial generation's desire to 'participate in the process' and not just be a recipient of a 'polished product'. Further, the methodology takes advantage of an enormous opportunity (viz. that many African youths have a passion for poetry and performance) and a practical reality (that not all translators are poets, but many poets can be trained to become translators). ${ }^{2}$

These bodies of knowledge, which undergird the methodology being espoused in this article, are first discussed, and then an empirical study is presented in which Zulu youths translated and performed some Zulu psalms using the form of traditional Zulu praise-poetry.

\section{Undergirding theories Orality criticism}

The oral heritage of much of the biblical text is an established fact today, particularly when the text is read aloud in the original language (Gunkel 1967; Niditch 1996:11). In many communities in Africa, the oral domain continues to dominate, even for those who are literate. Indeed, as Tshehla (2003:178) observes: 'How useful is a Bible "written" by literate people within a largely "oral" milieu?' Clearly the text must be prepared with an oral recipient in mind (Stine 1988:166). This requires mimicking the oral thinker and organising thoughts based on sound rather than sight (Harvey 1998). The translator must learn to 'think in mnemonic patterns ... in heavily rhythmic, balanced patterns, 2.Nida and Taber (1969:159) observe that 'artists are born not made', although some training is helpful. 
in repetitions or antitheses, in alliterations and assonances, in epithetic and other formulaic expressions' (Ong 2002 [1982]:34). It is, however, not enough to simply include certain formulas and transitions. 'We must go further, and consider the actual structure of the oral discourse of the culture in which we are translating' (Stine 1988:166).

An example of a case in which this has been done and where biblical poetry has been successfully translated into an African language, is described by Wendland (2002:168). Chichewa translators, following the pattern of oral ndakatulo poetry, translated Psalm 23 using features of the indigenous form: 'elaborately patterned repetition, rich thematic symbolism, novel figurative language, culturally resonant key terms, subtle phonic artistry, (and) the skilled use of ideophones or exclamations'. This is most encouraging and suggests that careful attention to features of oral discourse in the receptor language can yield promising returns.

\section{Performance criticism}

It is argued that many parts of the Scriptures (particularly the poetic sections) were prepared to be performed (recited, chanted or sung) rather than to be read. The major advantage that performance brings to a text is that it includes a richer way of interpreting a text and another dimension of communicating the message (i.e. visually, as well as aurally).

Firstly, noting performative features in the source text can be very enlightening in terms of understanding a text, and then, secondly, in communicating the message. For example, Psalm 134 takes on new meaning when participants act out the three verses: it becomes clear there are two voices: that of the pilgrims and that of the priest(s). Similarly, Psalm 145, which has been described as 'a litany of divine titles' (Dahood Mitchel 1970:337), becomes a wonderful means for a leader and community to enter into praise in a call-response format once the performance features in the text are discerned. The text makes clear that two voices are alternating, and in Africa, such a form of singing is common. Even a lament psalm like Psalm 22 has strong performative features, with initially the psalmist and God on stage (in Scene 1, vv. 1-22) and then the psalmist, congregation and God on stage (in Scene 2, vv. 23-31).

Moreover, when one performs the psalms, the message can be strengthened through using appropriate paralinguistic and extra-linguistic features (e.g. gestures, facial expressions, tone of voice, speed and volume of delivery, props, clothes, and different speakers). Even poetic devices can be highlighted, for example chiastic features in a segment (such as A, B, C, B', A') can be physically illustrated by having five speakers, in the correct order, with $A$ and $\mathrm{A}^{\prime}$ wearing the same clothes, and B and B' similarly. Then C (in the middle of the group) would stand out and indicate that the words spoken by $\mathrm{C}$ are the most important in this segment. Inclusio could be also represented physically on the stage, with the persons delivering the opening frame and closing frame surrounding those speaking the rest of the text. Even parallelism (step-down or step-up ${ }^{3}$ ) could be represented physically with the speaker giving the first line (standing on a dais) and then stepping down or up as he or she gives the parallel line (possibly addressing a different direction to indicate that it is not a duplicate, but adding or summarising content).

Communicating through performance is far more dynamic for an audience, engaging more of their senses and thus holding interest. Moreover, the audience plays an active role in the interpretation of meaning and the direction in which the performance moves. Through their interaction with the performer, the audience validates or corrects the meaning presented and participates in the singing of choruses or other opportunities made available to them. In these ways, the text is restored to its public ownership.

\section{Literary translation with a focus on performative features}

This methodology seeks to be sensitive to the phonic artistry and rhetorical power of the source text, and to use the richness of local indigenous art to communicate the message. It is a functional-equivalent strategy, ${ }^{4}$ aiming to translate all the functionality of poetic features in the source text (aesthetic, rhetorical, emotive, performative, expressive and interpersonal, as well as the traditional functions of informative and imperative). Such (literary) translation:

\begin{abstract}
... has the inherent verbal power to make a cognitive and emotive impact on people who probably never realised that the Word of God could speak to them so beautifully and powerfully in their mother tongue. (Wendland 2004:287)
\end{abstract}

The performative function is one that has been little understood or appropriated, and yet, it can yield rich returns as indicated in this article.

\section{Reception theory}

In Reception Theory, the reader is given a creative role (Darr 1998:29) and is a full participant in the production of the meaning of the text. This is necessary, as the meaning of the text is not fully self-evidencing, but has gaps or indeterminacies which must be filled by the reader, using his or her imagination, experience and societal conventions (Iser 1974). Such gaps in understanding may arise due to ambiguities in translation, the use of metaphors or polysemous words (Fretheim 2007:51). The way the gaps are filled must satisfy the following criteria: harmonise with the context of the whole text (Foley 1991:41); take cognisance of the historical and sociological context of the text; and fit in with the needs and experience of the reader. Several scholars focus on the last of these three criteria. For example, Gadamer (1991) posits that meaning results from 'a fusion of

3. Hebrew poetry is typically step-up (with the second colon extending the meaning of the first), whereas Zulu poetry tends to be step-down (with the second colon giving a summarised or generalised version of the first).

4.The form of the receptor text may be different from that of the source text, as long as it is similar in function (see Wendland 2004:269, 277-278). 
horizons' of the reader and the text. Soukup (1997:103-104) maintains that the reader brings to the text his or her needs and prior experience, and meaning is negotiated within the range of possible meanings. Fretheim (2007:52) notes: 'What we bring to the text will inevitably affect what we see in the text.' The gaps provide hermeneutic opportunities for the hearers to apply the text in a meaningful way to their personal situations. This was found to be the case in some of the interpretations in the empirical study.

\section{'Crowd-sourcing'}

An underlying premise to this methodology is that 'a gift for poetry' or a sensitivity to language is distributed throughout the population and not restricted to (and not necessarily present within) professional 'Bible translation teams'. Wendland (2004:68-70) maintains that the essential elements needed for poetic translation are a strong sensitivity to the sounds of the receptor language and the forms of poetry it uses, as well as an inbuilt sense of rhythm. A person who has such skills can be taught to recognise and utilise 'the principles of language manipulation' involved in translation.

Shirky (2010) highlights the opportunity available today to tap the skills and enthusiasm of the 'ordinary person' in contributing to projects about which he or she is passionate. Such opportunity has arisen as a result of advancing technology and people having more 'disposable time'. Shirky's model is to use the internet, but however the skills are harvested, the principles are the same. In this study, physical workshops were the modus operandi, but I later suggest that a similar methodology could be tried online.

An obvious advantage of 'crowd-sourcing' is that, as more people become involved in such a project, creativity multiplies as does commitment and public interest. Moreover, as Shirky (2010:153-154, 211-212) points out, there are times when the gains obtained by the process (e.g. buying into the project and taking ownership) exceed those of having a perfect product. He notes, too, that one can no longer clearly distinguish between products developed by amateurs and those developed by professionals. With the upcoming generation of isiZulu speakers being millennials (who expect to be participants in the process and not simply passive recipients of a 'completed Bible'), it is necessary to find ways in which those interested can be involved.

\section{Empirical study}

Zulu youths, interested in poetry and music ('ordinary' members of the community with no previous background in translation), were invited to participate in workshops to learn how to translate psalms of praise. Workshops were held in Durban and Pietermaritzburg (PMB), with four different groups of Zulu participants (mainly youths, but one group included members of the church choir, some of whom were older). Topics covered in the training included basics of Bible translation, principles of orality and performance as means to communicate effectively, indigenous music and features of Zulu and Hebrew praise-poetry. I had already prepared a literary-rhetorical analysis of the psalms under study, and the main features of the Hebrew texts were part of the preparation for translating. At the end of each session, participants spent an hour or so converting their translation into a performance (utilising song, rap or the spoken word). In two of the four workshops, a public performance before the church and friends or family was made at the end. The data is extensive and is available online in its entirety (Dickie 2017). However, for the purposes of this article, a few results from each step in the process are given.

\section{Features of Zulu oral art}

In order to assess how successfully the Zulu poets used features of their oral art, it is necessary to list some of the most important and relevant characteristics discovered during the workshop study of izibongo [Zulu praise poems]. These are listed below, with examples following:

- repetition of words, phrases (formulas), sounds (as in alliteration and assonance) and wordplay (e.g. ideophones);

- the use of parallel structures (including tricola), as well as chiasm and inclusio;

- the importance of rhythm (poetic and musical).

\section{Example 1}

'Izibongo of Shaka' (African Poems n.d.) shows repetition of key words as a common feature. In lines 28-29 (below), 'devour' occurs 4 times, and in the whole poem (114 lines), it occurs 31 times:

28 He who while devouring some, devoured others

29 And as he devoured others, he devoured some more;

\section{Example 2}

'Izibongo of Dingane' (Cope 1968:109, line 303) shows natural alliteration (resulting from the prefix si) and artificial alliteration (from $\mathrm{dl}$ - and $n d l-$ ):

l-si-dla-ngu-dla-ngu e-si-nje- [He is rough as the ear of an nge-ndle-be ye-ndlo-vu elephant.]

\section{Example 3}

'Izibongo of Ndaba' (Cope 1968:41) shows perfect parallelism:

Obeyalala wangangemimfula, [Who when he lay down was the

Obeyavuka wangangezintaba. size of rivers,

Who when he got up was the size of mountains.]

\section{Example 4}

'Izibongo of Senzangakhona' (Cope 1968:77, 42-44) shows 3-fold parallelism (tricola):

UMlunguzi wezingoje,

Owalunguz' ingoje yomfowabo,

[Peerer over precipices

Who peered over the precipice of his brother

Owalunguz' ingoje kaZivalele. Who peered over the precipice of Zivalele.] 


\section{Example 5}

An inclusio is formed by the metaphor of an 'axe' (in line 7 and 114 of Izibongo of Shaka), at the beginning and end of the poem, highlighting the last line (outside the inclusio) as prominent.

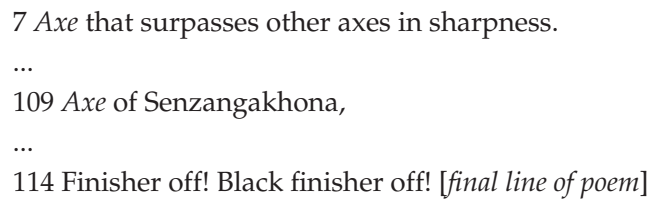

\section{Example 6}

The metaphors used in Zulu poetry are very colourful and intense or violent. In the Izibongo of Shaka, metaphors include 'chopping', 'thundered', 'kicking', 'stabber' and 'viper'. Shaka is referred to as a 'beast' or 'lion / leopard'. It is a common metaphor to praise the Zulu king or chief as a lion, leopard or elephant. For example, the Zulu poet, Msimang (1980:38), describes the incumbent (Chief Buthelezi) as a lion, tearing and smashing his rivals.

\section{Example 7}

Gunner (1990:195) gives an example of chiasm from Zulu poetry:

Chopper down of the big tree;

the little one falls on its own.

\section{Example 8}

The hymn excerpt below (Shembe \& Shembe 2010 - Hymn 4) shows a consistent rhythm, resulting from a fixed number of stressed syllables in each poetic line (despite the fact that the last line has only one word):

$\begin{array}{ll}\text { Yiza namuhla } & \text { [Come today } \\ \text { Yiza ngamandla } & \text { Come quickly (lit: through power) } \\ \text { Bheka isango } & \text { Look, the gate } \\ \text { Selivuliwe } & \text { Is now open.] }\end{array}$

\section{Example 9}

An example of literary rhythm (where an established pattern of ideas is broken to give focus to the main thought) is apparent in this example from Izibongo of Shaka:
1. UTeku lwabafazi bakwaNomgabhi,
[The joke of the women of Nomgabhi,
2. Betekula behlez'emlovini,
Joking as they sat in a sheltered spot,
3. Keth' uShaka kakubusa kakuba nkosi
Saying that Shaka would not rule, would not become chief
4. Kanti unyak' uShaka ezakunethezeka.
Whereas it was the year in which Shaka was about to prosper.]

The first three lines are linked, with line 2 developing line 1 , and line 3 developing both lines 1 and 2. Then line 4 is counter-expectation, to give prominence to the final thought.

\section{Example 10}

The next example (from Izibongo of Shaka) also shows a break in the established rhythm, to give prominence to the praise name 'young viper' (line130):

124 He attacked Macingwane at Ngonyameni,

$125 \mathrm{He}$ attacked Mangcengeza of the Mbatha clan,

$126 \mathrm{He}$ attacked Dladlama of the Majolas,

$127 \mathrm{He}$ attacked Nxaba son of Mbhekane,

128 He attacked Gambushe in Pondoland,

129 He attacked Faku in Pondoland.

130 The young viper grows as it sits

\section{Features of Zulu music}

Participants noted that Zulu music is based on an interplay of various rhythms, with features such as rhyme and harmony less important. As isiZulu (like many African languages) is tonal, it was noted that the melody of the words must not contradict the melody of the song. Moreover, songs using known melodies (particularly Western tunes) are not appropriate, as the stress rarely lines up on the correct syllable. Thus, the participants were encouraged to compose their own new melodies, which many of them were able to do successfully.

\section{Compositions}

From the workshop discussion, participants were aware of exegetical and poetic issues in the Hebrew text, as well as traditional forms of Zulu oral art and music. With all this in mind, they then proceeded to make their own translations (in isiZulu) of the psalm under study.

Once their translations had been briefly checked for exegetical accuracy, the compositions were transformed into performances. This required selecting a limited number of verses, identifying the main idea and choosing a presentation method. Some used a mix of rap, spoken poetry and/or song, while others used a recorded beat to provide background rhythm to their item. Attention was given to the key idea in the psalm in various ways, for example, through slowing down the rhythm, or introducing a different presentation form (e.g. having the main idea as the chorus of a song, and the other concepts as spoken verses).

Some examples follow to illustrate how poets used their oral art to produce translations which captured the semantic and emotive content of the original text.

Translation 1: Psalm 134 (Item 17): ${ }^{5}$
1a. Nakani nidumise uSimakade,
[Attention! Praise the LORD,
1b. nina nonke zinceku zikaSimakade, you all servants of the LORD,
1c. nina enibambelele kuSimakade you who hold on (intensely) kunzima. to the LORD in difficulties
2a. Phakamiselani izandla
Lift up hands,
2b. nidumise uSimakade praise the LORD.
3a. Makanibusise uSimakade
3b. uSimakade owenze umhlaba May the LORD bless you, nezulu. the LORD who made earth and heaven.]

5.The 'Item' number refers to Appendix $1 \mathrm{a}$ and $\mathrm{b}$ (words) and Appendix $2 \mathrm{~b}$ (videos) of Dickie (2017). 
This poem uses an array of oral and poetic features (e.g. alliteration, assonance, repetition, parallelism, inclusio, tail-head linkage, terse language and rhythm). In the performance, verse 3 was highlighted as being in focus, with the singer significantly increasing the beat before colon $3 \mathrm{a}$ and slowing down the pace as he sang the final words in colon $3 \mathrm{~b}$. These paralinguistic devices contributed to the meaning conveyed.

The poet's interpretation of 'stand by night' (v. 1) as 'hold on intensely to the LORD in difficulties' is a clear example of his context colouring his interpretation of the text. Both the Hebrew words concerned can be interpreted that way, although no English translation does so. However, the ambiguity or gap in understanding allowed the reader to bring his own difficult circumstances into his interpretation (in line with Reception Theory).

\section{Translation 2: Psalm 134:3 (Item 22):}
3a. Angathi uSimakade wase Zioni,
3b. angehlisela isibusiso kinina,
3c. yena owenze izulu nomhlaba,
3d. angathi angani busisa.
[May the LORD from Zion, may he give blessing to you, he who made heaven and earth, may he bless you.]

The poet above added an additional line into verse 3 , to facilitate a good rhythm. The parallel idea also serves to emphasise the request for God to bless. There is also much use of assonance (-i in 3a, 3b, 3d) and alliteration (ang- in 3a, $3 b, 3 d$, as well as $z-$ in $3 c$ ) which contribute to the aesthetic beauty and memorability of the poem.

\section{Translation 3: Psalm 134:3 (Item 23):}
3a. Engathi Inkosi yamakhosi inganibusisa eyaseSiyoni,
3b. engathi anganibusisa
3c. lo owahlukanisa ubumnyama nokukhanya,
3d. owahlukanisa amanzi nolwandle.

\begin{abstract}
[May the Lord of lords may he bless you from Zion, may he bless you

this one who separates darkness and light, who separates water and sea.]
\end{abstract}

This poem shows alliteration (nga- in $3 a, 3 b)$ and assonance (-o in $3 c, 3 d)$. But what is particularly interesting is how the poet has again used two parallel cola to translate 'Creator of heaven and earth'. The two images $(3 \mathrm{c}, 3 \mathrm{~d})$ are also drawn from creation, although more specific than the general idea in the Hebrew text.

\section{Translation 4: Psalm 134:}

Brueggemann and Bellinger (2014:560) note that the Hebrew text of Psalm 134 includes two chiastic structures in verses 1 and 2:

- 'bless' / 'you servants' / 'you who serve' / 'bless'

- 'bless the LORD' / 'house of the LORD' / 'holy (place)' / 'Bless the LORD'

Chiasm is also found in Zulu poetry (as apparent in Example 7 earlier) and serves a similar function in both languages, viz. to hold the text together as a unit and to assist

with memorability. Many of the Zulu poets included some form of chiasm in their translations of Psalm 134. For example, the poet below (Item 3) used chiasm in 1c and 1d-e:
1a. Bukani Dumisani uJehova,
1b. nina nonke zinceku,
1c. zikhonzi zonke zika Jehova,
1d. omile endlini uJehova
[Look! Praise the LORD,
you all servants,
worshippers all of the LORD,
who stand in the house (of) the LORD
1e. yokukhonzela imini nobusuku. worshipping day and night.]

Others introduced a chiastic structure into verse 3 (although the Hebrew did not contain such). Use of poetic devices is one way of marking the most prominent verse and, in this psalm, verse 3 is the peak. The Hebrew indicates this by introducing a change in the verb form (v. 3 has a subjunctive after a string of imperatives), but chiasm (as used by the Zulu poet below $)^{6}$ can also add weight to the verse and display its prominence:
3a. uSimakade wase Siyoni,
3b. makahlise izibusiso phezu kwenu.
3c. Engathi ningathela izibusiso
3d. kulowo owadala izulu nomhlaba.

[The LORD from Zion, may he bring down blessings upon you.

May you bear blessings from he who created heaven and earth.]

Translation 5: Psalm 93

A dominant rhetorical feature, presented in Psalm 93, is the three-fold parallelism in both verses 3 and 4 . It provides a graphic representation of the 'flood' growing in intensity. For example, verse 3:

The floods have lifted up

The floods have lifted up their voice

The floods have lifted up their voice on high

It was noted that parallelism is used in Zulu poetry, including three-fold parallelism (as in Example 4 earlier). Thus, most of the Zulu poets maintained the use of this poetic device, although they changed the metaphor(s) in some cases. For example (Item 12):
3a. Nakuba isitha sibhodla okwebhubesi,
3b. Nakuba izivunguvungu zisihlasela ngamandla,
3c. Nakuba umoya uvunguza ngamandla,

4a. inamandla iNkosi ngaphezu kwebhubesi

4b. inamandla iNkosi ngaphezu kweziounguvungu,

4c. inamandlaNnkosi ngaphezu kwezioungu-vungu eziounguza ngamandla.
[Even tho' the enemy roars like a lion,

Even tho' strong winds attack us with force,

Even tho' the wind is blowing strongly with power, the LORD is more powerful than the lion the Lord is more powerful than strong wind the Lord is more powerful than the strong wind that is blowing with power.]
This translation of Psalm 93:3-4 shows the use of colourful metaphors (lion and wind) instead of the image of 'floods' as in the Hebrew. Again, there is a lot of repetition, three-fold parallelism (in both v.3 and v.4), and assonance.

6.See Dickie (2017: Appendix 1a: Item 24). 
Translation 6: Psalm 93:3-4 (Item 7):

\begin{tabular}{|c|c|}
\hline $\begin{array}{l}\text { Noma umfula ungagczwala } \\
\text { uphuphume, }\end{array}$ & $\begin{array}{l}\text { [Even if river becomes full, } \\
\text { overflowing, }\end{array}$ \\
\hline $\begin{array}{l}\text { 3b. noma umlilo ungavutha } \\
\text { ubuhangu-hangu, }\end{array}$ & $\begin{array}{l}\text { even if fire burns with scorching } \\
\text { heat, }\end{array}$ \\
\hline $\begin{array}{l}\text { 3c. noma ulwandle lungenza } \\
\text { unonakalo, }\end{array}$ & $\begin{array}{l}\text { even if sea is doing great } \\
\text { destruction, }\end{array}$ \\
\hline $\begin{array}{l}\text { 4a. uJehova uNkulunkulu } \\
\text { unamandla }\end{array}$ & $\begin{array}{l}\text { the LORD God he is more } \\
\text { powerful }\end{array}$ \\
\hline $\begin{array}{l}\text { 4b. phezu komlilo omkhulu, } \\
\text { 4c. nangaphezu kwe-zi-vunga- } \\
\text { vunga zolwandle. }\end{array}$ & $\begin{array}{l}\text { above the great flames, } \\
\text { even above blowing of gale } \\
\text { of sea.] }\end{array}$ \\
\hline
\end{tabular}

This poet translated the metaphor of 'floods' (in the Hebrew) with other natural phenomena more relevant in the poet's context, viz. a river, fire and the sea (with a gale blowing). It is also typical of Zulu poetry to use more than one image to describe an idea; the layering of images strengthens the intensity being represented. Intensity is also represented by the ideophone in 3b, hangu-hangu. Although Hebrew does not make use of such a poetic device, ideophones are common in Bantu languages and appreciated by the audience as being a unique part of their oral art.

In the Hebrew, the metaphors in verse 4 relate to those mentioned in verse 3 (to indicate that the LORD is more powerful than the difficulties mentioned). The Zulu poet did this too by referring to 'flames' (cf. 'fire') ('flames' being more vivid, showing growing intensity), and with the water metaphor also growing in intensity (as in the Hebrew) from 'river' to 'sea doing great destruction', whipped by a 'gale'.

Translation 7: Psalm 93 (Item 6 excerpts):
1c. Jehova, uyingonyama ...
[LORD, you are the royal lion]
3c. sihlasela kuhle kwebhubesi,
[(the enemy) attacks like a (common) lion ...]

The composer of this translation of Psalm 93 introduced the metaphor of a 'lion' into the inclusio frame (vv. 1-2 and v. 5) where the Hebrew used the image of being 'girded with strength'. Then the poet re-used the same image (with a twist) in colon 3c: the word for 'lion' associated with the LORD (in 1c) is linked with royalty and the Zulu chief, but the one associated with the enemy (in 3c) is the word for a common lion. This suggests that the enemy may try to appear strong, but the real lion (or strong one) is the LORD. This seems to be a powerful insight.

\section{Performance innovations}

With regard to performances, there was also interesting innovation stemming from indigenous oral art, which added to the meaning or focus of the text. For example, a performance of Psalm 134 (Item 10) began with a chorus comprising the first colon (Mdumiseni uSimakade [May you praise the LORD]). This was sung several times before and after the spoken poetry performance of the psalm. The chorus gained the audience's attention, and through it being repeated several times, the main theme was emphasised and remembered.
A performance of Psalm 93 (Item 5) began with the thrumming of drums, followed by a chorus sung with a catchy rhythm, calling mothers and fathers to listen. The introduction continued for a minute and a half, with the audience joining in. Then, with humming in the background, a poet spoke the words of the psalm. At the end, the group hummed the tune again twice before singing the chorus twice. This performance was very well received. The audience seemed to enjoy the catchy introduction and their attention was engaged before the message of the poem began.

\section{Some comments from interviews ${ }^{7}$}

Interviews conducted with audience members and participants revealed benefits that they perceived. These included:

- Memorability of the words (when in the form of a song), for example:

'With the message they did using drums, I can even recall the scripture they used ... It is not easy to forget the song.' (Interview 1)

- The message was appreciated for being clear and contextualised, for example:

'[Most people will enjoy singing the songs] because the translation used is much easier to understand than the original translation we have.' (Interview 5)

- The performed message was accessible to all, for example:

'... even those people who cannot read for themselves, they can understand the psalms or translation through hearing it sung or recited as a poem.' (Interview 4)

- Being able to participate in the process of 'Bible translation' was highly valued, for example:

'[Being part of the workshop] I discovered the potential of transforming the scripture ... by understanding the context of the psalms. I have learned to be part of the process of transforming the scripture for my context.' (Interview 6)

- Being able to engage with the biblical text was highly valued, for example:

'[Being part of the workshop] will change the way I engage with the scripture because I have learned better and different ways to approach and understand it.' (Interview 5)

- The translations were evaluated to be 'Scripture', for example:

'[People will enjoy singing the songs] because of the message and it still part of the scripture, not something we came up with.' (Interview 6)

\section{Discussion}

My doctoral work (Dickie 2017) sought to equip interested 'ordinary speakers' of isiZulu with basic training in Bible translation to see if they, drawing on their heritage of oral art, could contribute to a more poetic, culturally-sensitive translation of biblical poetry. The results suggest that even fairly minimal training given to 'poetry fans' enabled them to make beautiful and powerful translations of some biblical psalms. Their sensitivity to Zulu poetic features and those of 7.All interviews can be seen in Dickie (2017: Appendix 2c). 
Hebrew, as well as aspects of Zulu rhythm and features of orality and performance, enabled them to compose and perform poems that spoke to the hearts of their audience and empowered them through the process.

The main obstacles in involving interested persons in the process of Bible translation are logistically related to time scheduling, distance and the need for trainers to equip the participants in the necessary skills. These problems can be overcome by having an online 'group' where interested persons can learn, compose, perform, share and exchange ideas about a particular psalm under study. They could also comment on drafts of a new translation or be involved in 'community checking'. Such an online platform has great potential, and once established, it would be easy to make modifications for any other language. Hopefully such a platform will become a reality before too long.

\section{Conclusion}

There are many 'poetry fans' among African communities people who love to play with language and to compose their own poems. Thus, the opportunity is there to draw in such people to share in the translation process for their own delight and enrichment, but also to strengthen the aesthetics and rhetorical force of the official translation. Their creativity can stimulate the production of lyrical and thoughtprovoking translations which many would enjoy.

Indeed, for many young people today, the gains of participating in the process of 'translation' and making their own version, owned by them, are very significant and not to be derided. The official translation may be the one which is published and used in the church liturgy, but the psalm that speaks to the heart could well be the one composed by the individual.

This methodology also allows for a community's rich indigenous heritage of oral art to inform the translation. In addition, it points the way for various new opportunities: new ways of presenting Scripture during the Sunday service, new ways of discipling youth through their participation in online translation forums, and new ways of engaging an audience who expects a full sensory experience, engaging the eye and the ear.

\section{Acknowledgements}

This article is partially based on data and ideas from the author's thesis for the degree of Doctor of Philosophy in the School of Religion, Philosophy and Classics, University of Kwa-Zulu-Natal, Pietermaritzburg, South Africa, with supervisors Prof. Jonathan Draper and Dr Ernst Wendland, received 2017, available here: http://hdl.handle.net/ $10413 / 14223$.

\section{Competing interests}

J.F.D. declares that no competing interest exist.

\section{Author's contributions}

J.F.D. declares that she is the sole author of this article.

\section{Ethical considerations}

This article followed all ethical standards for carrying out research without direct contact with human or animal subjects.

\section{Funding information}

This research received no specific grant from any funding agency in the public, commercial or not-for-profit sectors.

\section{Data availability}

Derived data supporting the findings of this study are available from the corresponding author, J.F.D., upon reasonable request.

\section{Disclaimer}

The views and opinions expressed in this article are those of the author and do not necessarily reflect the official policy or position of any affiliated agency of the author.

\section{References}

African poems, n.d., Shaka, viewed n.d., from http://www.africanpoems.net/praise/ shaka/.

Bassnett, S., 2014, Translation, Routledge, London.

Brueggemann, W. \& Bellinger, W.H., 2014, Psalms, Cambridge University Press, New York, NY.

Cope, A.T. (ed.), 1968, Izibongo Zulu praise poems, Oxford University Press, London.

Crafford, D., 1997, The Bible in audio-format: Report to the Bible Society of SA, Institute for Missiological and Ecumenical Research, Pretoria.

Dahood Mitchel, S.J., 1970, The Anchor Bible Psalms III (101-150), Doubleday, New York.

Darr, J.A., 1998, Herod the Fox: Audience criticism and Lukan characterization, Sheffield Academic Press Ltd., Sheffield.

Dickie, J.F., 2017, 'Zulu song, oral art, performing the psalms to stir the heart', PhD thesis, University of KwaZulu-Natal, viewed n.d., from http://hdl.handle. net/10413/14223.

Foley, J.M., 1991, Immanent art: From structure to meaning in traditional oral epic, Indiana University Press, Bloomington.

Foley, J.M., 1995, The singer of tales in performance, Indiana University Press, Bloomington, IN.

Foley, J.M., 2012, Oral tradition and the Internet: Pathways of the mind, University of Illinois Press, Urbana, IL.

Fretheim, T., 2007, 'The authority of the Bible and the imaging of God', in W.P. Brown (ed.), Engaging Biblical authority, pp. 45-52, Westminster John Knox Press, London.

Gadamer, H.-G., 1991, Truth and method, 2nd rev. edn., transl. J. Weinsheimer \& D.G. Marshall, University of California, Berkeley, CA.

Gunkel, H., 1967, The Psalms: A form-critical introduction, Fortress, Philadelphia, PA.

Gunner, E., 1990, 'Wand or walking stick? The formula and its use in Zulu praise poems', in I. Okpewho (ed.), The oral performance in Africa, pp. 185-207, Spectrum Books Ltd, College Station, TX.

Harvey, J.D., 1998, Listening to the text, oral patterning in Paul's letters, Apollos, New York.

Hermanson, E.A., 2004, 'Missionary translations of the Bible into the Zulu language', in G.L.O.R. Yorke \& P.M. Renju (eds.), Bible translation and African languages, pp. 41-58, Acton, Nairobi.

Iser, W., 1974, The implied reader: Patterns of communication in prose fiction from Bunyan to Beckett, John Hopkins University Press, Baltimore, MD.

Msimang, C.T., 1980, Iziziba ZoThukela, Via Afrika, Pretoria.

Nida, E.A., 2003, Fascinated by languages, John Benjamins, Amsterdam.

Nida, E.A. \& Taber, C.R., 1969, The theory and practice of translation, Brill, Leiden.

Niditch, S., 1996, Oral world and written word: Ancient Israelite literature, Westminster John Knox Press, Louisville, KY. (Library of Ancient Israel).

Ong, W., 2002 [1982], Orality and literacy: The technologizing of the word, Metheun, London. 
Rhoads, D., 2006, 'Performance criticism: An emerging methodology in Second Testament Studies - Part I', Biblical Theology Bulletin 36(3), 118-133. https://doi. org/10.1177/014610790603600304

Shembe, I. \& Shembe, G., 2010. Shembe hymns, ed. C. Muller, transl. B. Mthethwa, University of KwaZulu-Natal, Pietermaritzburg.

Shirky, C., 2010, Cognitive surplus: Creativity and generosity in a connected age, Penguin Press, New York, NY.

Soukup, P.A., 1997, 'Understanding audience understanding', in P.A. Soukup \& R. Hodgson (eds.), From one medium to another: Communicating the Bible through multimedia, pp. 91-107, Sheed \& Ward, Kansas City, MO
Stine, P.C., 1988, 'Sociolinguistics and Bible translation', in P.C. Stine (ed.), Issues in Bible translation, pp. 146-171, Sage, Los Angeles, CA. (United Bible Societies Monograph Series, 3).

Tshehla, M.S., 2003, 'Translation and the Vernacular Bible in the debate between my traditional and academic worldviews', in J.A. Draper (ed.), Orality, literacy, and colonialism in Southern Africa, pp. 171-187, Cluster Publications, Pietermaritzburg.

Wendland, E.R., 2002, Analyzing the Psalms: With exercises for Bible students and translators, 2nd edn., SIL, Eisenbrauns, Dallas, TX.

Wendland, E.R., 2004, Translating the literature of scripture, SIL Int., Dallas, TX. 